\title{
A THEISTIC, UNIVERSE-BASED, THEODICY OF HUMAN SUFFERING AND IMMORAL BEHAVIOUR
}

\author{
JEROME GELLMAN \\ Ben-Gurion University of the Negev
}

\begin{abstract}
In what follows I offer an explanation for the evils in our world that should be a live option for theists who accept middle knowledge. My explanation depends on the possibility of a Multiverse of radically different kinds of universes. Persons must pass through various universes, the sequence being chosen by God on an individual basis, until reaching God's goal for them. Our universe is depicted as governed much by chance, and I give a justification, in light of my thesis, for why God would have people pass through a universe of just such a sort.
\end{abstract}

Here I am going to present something between a defence and a standard theodicy to help explain human suffering and immoral behaviour. A defence is an argument purporting to show that it is logically possible for God to exist together with the evils of our world. A standard theodicy purports to provide a true explanation for why God allows the evils of our world. At its most successful, a theodicy will satisfy everyone, even atheists, who will then admit that if God exists, it is reasonable to think God would allow our world's evils. More limited success will come when a theodicy is only theistically reasonable, that is, is reasonable only on grounds taken from standard theistic traditions, together with what else compatible with that most people would find reasonable. Now, in what follows, my aim is not to present simply a logically possible scenario where God and our evils exists. So it is not a defence that I propose. Yet, what I present is not what an atheist is going to accept, nor even what is grounded solely in standard theistic ideas together with what most people find reasonable. So what I am presenting is not a standard theodicy, not even a theistically reasonable one. Yet, it is something close to a theistically reasonable theodicy. That is because my theodicy 
uses some standard theistic ideas, and other ideas which I urge as a live possibility from a theistic point of view. A 'live possibility' is one whose truth is attractive to a theist, even if not included in standard theism. This will include attractiveness due to being an extension or further development of extant theistic ideas, and due to ideas consistent with theism that will be attractive to the theist because they help solve the problem of evil and are not implausible on theistic grounds. I will consider my theodicy successful to the extent theists will agree that it is a live possibility for why God would allow at least much of the world's evils, and thus help remove the sting from the problem of evil.

At the start, my theodicy is limited in its attractiveness to those for whom it is a live option that God has what is called 'middle knowledge." God having this knowledge means that God knows not only what will happen, but also knows for every possible person that God could create, what that person would do of his own free will in each situation were God to create him. So God knows that if God creates Pharaoh, that when faced, in specific circumstances, with the choice whether to free the Israelites, whether Pharaoh will freely choose to free them. On the basis of such knowledge, God can decide who God wants to create and not create, depending on whether the free actions they undertake if created are what God wants to exist. In what follows I assume God has middle knowledge, a common theistic belief.

Psalms 97:2 tells us that God is surrounded by 'clouds and thick darkness. The same verse informs us that, 'righteousness and justice are the foundation of His throne'. So even though we face God within a dark cloud of unknowing, we theists know or believe that God is supremely good - righteous and just. God's 'goodness' includes that (a) God radiates all and only goodness to others, to the extent of God's capability, which is considerable, and (b) God does so only for the sake of others, nothing for God's own sake. So, God creates, in an act of goodness pouring out of God to that which is other than God, for the sake of others.

The greatest possible good God can do is arrange it so that creatures freely become good, like God is. Becoming good like God has supreme intrinsic value, and has extrinsic value in bringing creatures close to God. Being good, as God is, is to be close to God. So that is what God

\footnotetext{
${ }^{1}$ For defences of middle knowledge see Thomas Flint, Divine Providence: The Molinist Account (Ithaca: Cornell University Press, 1998), and Eef Dekker, Middle Knowledge (Leuven: Peeters Publishing, 2000).
} 
wants, and does. Of course, goodness in the created order is finite as opposed to God's infinite goodness. So in that respect no created being can be good quite like God. Also, being a creature entails having minimal creature-needs that must be satisfied in order to become and continue to be good. So in that respect as well no created being can be good like God. To be good like God in my sense, then, will be to radiate all and only goodness to others, doing so only for the sake of others, nothing for one's own sake, to the extent possible within one's creaturely status and individual capacity. One who does good to others for the pride of being good is not like God. Also, one who is good in order to enjoy - for his own sake - the divine beatitude everlasting, will not be like God. To be like God one must be and do good for the sake of others, not for one's own sake. This includes wanting to be like God not for one's own sake, but for God's sake, that is, because that is what God wants you to be. If one (ostensibly) wants to be like God for one's own sake, then one falls short of wanting to be like God. That is because there is nothing God wants for God's own sake.

Now, God might be able to create some creatures that from the very first moment are like God, in my sense. Various religions claim to have sited such creatures among us. However, God creates others as well, those who God knows will be close to God only through a process of becoming close to God. God does so because God is good and wishes to confer this good on as many creatures as possible.

There are constraints on which creatures God can create so that they will come close to God. Let us call 'persons' those creatures who have the capacity to come close to God. These include human persons. Of these, God instantiates a maximal set of possible persons of which God knows that if God creates them they will fulfil God's goal of becoming close to God, with God providing environments and the degree of divine assistance that God knows will lead to success. (Here God uses middle knowledge.) If there is no one such maximal set, God selects one set of such persons to instantiate.

Secondly, recall that in my sense a 'person' is a creature who has the capacity to come close to God by becoming good, like God. However, God will not create just any maximal co-possible set of persons. God will create persons God knows will become like God only when the process of their becoming like God will be morally justified, in terms of the cost/benefit of good and bad. God, then, creates only persons that fulfil these requirements, to increase the good of creation as far as 
possible. Universal salvation of persons is the worthy goal for God to have in becoming a creator, and God guarantees this from the start while honouring creaturely freedom, consistent with behind the scenes divine assistance. By selecting whom he creates, God guarantees the outcome.

In creating persons who must undergo a process of growth to become like God, God gains an extra value over creating only persons it is possible to create ready-made good like God. There are two kinds of values in the existence of goodness. One is the value of having goodness. The second is the value of obtaining goodness. ${ }^{2}$ Overcoming a lack of goodness is itself a value, in addition to the resultant good. When a person cannot walk because of injury and she, her family, and her medical caretakers persevere until she walks, the resultant good is twofold: the good of now being able to walk, and the good of having achieved the ability to walk, to have overcome adversity and discouragement. Developing a good character possesses value above the value of having a good character from the start. So when God creates persons who must develop into being close to God, God gains the value of one's becoming like God, in addition to the goodness of being like God. God will do this in the best cost/benefit way possible for each person. The value of becoming close to God is so great that it will massively trump the amount of evil God will allow for the process of each person becoming like God to succeed.

The universe we inhabit seems to present a story very much at odds with the idea that every creature that God creates who can be like God eventually becomes like God, a source of goodness and goodness only. There are children who die young, never having had a chance to develop beyond their first years. There are people who suffer lives of pain and suffering, their consciousness so filled with adversity that no room remains to even think about much else. There are people who are crushed by life, dying in sadness and defeat. Then there are those whose entire life is a grasping for self-advantage and self-survival. There are those who predicate their lives on harming other people in criminal and immoral behaviour; and those who have been so wronged and so hurt by life that hate and fear are their motto. Finally, there is the great bulk of humankind who seem to achieve some degree of goodness in their lives but who we cannot by any means think of as having become like God. Our universe seems pretty clearly to defeat my theodicy.

${ }^{2}$ This is a basic tenet of panentheism, where both the achievement of value as well as original value are assigned to God. However, this principle applies equally to theism. 
That might be the case were we to suppose that our universe is the only one God creates. Yet, there is no good a priori reason for a theist to assume this. This is a narrowness of vision. God's creative abilities are vast. Accordingly, my theodicy posits a plurality of universes, universes with diverse laws and substances, some with make-ups and structures beyond our imagination. This posit gains support from recent scientific advances that have led some to posit the existence of a 'multiverse', parallel universes independent from one another, diverse in ways I have indicated. ${ }^{3}$ My theodicy posits the existence of a multiverse as what would be in keeping with God's unlimited creative capacities and God's infinite goodness.

Save for the rare few, persons must occupy a variety of universes in succession. God has designed these universes just so, and places persons in those universes just so, so as to further God's goal of bringing persons to their ultimate goodness and closeness to God. Persons progress toward God's goal by passing from universe to universe. A person does not have to pass through every universe, and any two people need not go through the same universes. All depends on which types of universes they need to go through to in the end emerge being like God. There will be persons who will never appear in our present universe, their trajectory going through other universes. Persons who do exist in our universe might appear here more than once. Some might appear in one universe, then in another, and then return back to the first. You and I might cross each other at one universe in our journey toward being like God. Otherwise we might occupy different universes.

So our universe is only one of a multiplicity of universes, a possibly immense number of universes, available for persons to inhabit. These universes can be different from one another in their laws, material, composition, and in the kinds of persons they have in them. There can be universes with very few people, or even with only one, solitary person. Universes provide the transition conditions, natural and social, necessary for all persons who are to become like God.

Here I must mention two dimensions of human goodness to be achieved. The first is the goodness a person has as an individual toward others. You ask me to help you apply a bandage to a cut in your arm, and I do so. The second is the goodness displayed by a person-inhabited

${ }^{3}$ On the evidence for a multiverse, see: Max Tegmark, 'Parallel Universes', Scientific American, May 2003. 
society in its structure and functioning, the result of a cumulative and cooperative effort by individuals. We, as a society, make hospitals to treat people when they get severe cuts in their arms. God has created us as social-political beings so as to increase the kinds of goodness that will result from our being like God. As a result, there are further determinants of what universes a person can inhabit. That is because the goodness that must come forth from a person must also be expressed in the creation and functioning of worthy societal structures. Hence, souls must be selected for universes so as to progress in them in tandem in creating societal goodness. God, in His great wisdom, knows how to choreograph the whole to achieve a God-worthy degree of goodness in the end. For each person the goal is to become like God both in her life as an individual and in her role in a God-reflecting society. ${ }^{4}$

For that reason the end-point of universes cannot be isolated individuals who become like God in emptying out self-concern and replacing it with concern for others. The end-point must include persons in an overarching social-structure to which they all contribute and which is a supreme expression of their goodness. These 'final' universes (no reason to suppose only one) are collectively the 'Messianic Age', where all persons will abide in a Messianic canopy of societal perfection - as much as is possible for created beings - in close companionship with God. ${ }^{5}$ The Messianic Age will be of such value that all the journeys of all the people through the universes, to come to that point, will be understood for what they were and will be appreciated for their having been worth the effort. In the end God will cure all the morally and spiritually sick, will ultimately free all who are morally and spiritually imprisoned, and will keep faith with those, morally and spiritually, asleep in the earth. ${ }^{6}$

${ }^{4}$ A Jewish kabbalist might add that God has created us as social beings so that ultimately we can imitate the goodness reflected by the supreme unity and harmony in the supernal divine realm. A Social Trinitarian might want to say that God has created creatures as social beings as a necessary condition of their becoming like God. Since God, in the Trinity, participates as a constituent in a supremely good society, so persons must come to constitute a supremely good society, if they are to be like God.

${ }^{5}$ The term, 'Messianic Age', I borrow from Jewish tradition, where it refers to a future time in our universe. The vision of the tradition was limited to only this universe, hence the place of ultimate redemption was necessarily limited as well. I take my multiverse version of the Messianic Age to be an application of the insight of tradition to a wider vision than possible long ago.

${ }^{6}$ This is a paraphrase from the traditional Jewish prayer book. 
The diversity of universes means that (as it were) 'all the time' parallel universes are going on in serving parallel tracks for successive universeprogressions for individuals. Two persons can occupy the same universe while being at different stages in their careers of developing likeness to God. And two persons can be at the same stage of development towards God yet be in different universes. God the creator and redeemer knows which universe suits each person in their journey to God and places them accordingly.

Personal identity is consistent with variations in the degree to which a person is self-centred or other-centred. It is the same person who was a self-centred sinner in the past and who now is a true repentant, dedicated to the good of others. This is an axiom of multiple universe progressions to God. It follows that God (for almost all persons) can choose to create a person initially, in her very first universe, at various places on the continuum of self-centredness or other-centredness which preserve her self-identity.

God must create a person at a level from which she will succeed eventually to reach the goal of becoming like God. Some persons might be such that if God creates them with a high degree of self-centredness, say, they will not reach the goal freely, even with some assistance from God. So God must create each person from the start at a level from which they will eventually turn out to be close to God. Furthermore, God will want to create a person at the minimum success-promising level for that person that God can, so as to increase as much as possible the value of becoming like God. This level is not necessarily the same as the minimum level from which a person, when initially created, will reach success. That is because God might not be able to implement that level. And the reason for that would be that starting from that level the process of becoming close to God will not produce a good/bad costbenefit that God can allow. So, the entry level for each created person will be the minimum possible level insuring success that at the same yields a trajectory of becoming like God properly proportioned between good and bad.

I have been carrying on about a person existing in successive universes until reaching the end-point of becoming like God. What sense can be given to sameness of individual identity through these universes?

To pin down individual identity through universes we should think of living through a universe as something like being totally absorbed in a film. While absorbed in a film, I can become bereft of all memories of 
the past, with no or only the barest self-consciousness. My consciousness is full of what transpires at the present time. When coming out of the total absorption in the film I again connect with my memories. I remember having come to the cinema, starting to watch the film, etc., and know it was I who was totally absorbed in the film and who then came out of it to be here this very moment. My individual identity runs through from beginning to end. Just so, when we are living in a universe, we might be totally absorbed in living in that universe. We might not be aware of any self-identity outside of our existence in that particular universe. (On the other hand, there might be universes where our memories of prior universes are quite alive, or dim, these enough to insure a self-identity consciousness throughout.)

Concentrating on those universes where a person has no memory of other universes she has inhabited, personal identity across universes can be secured in various ways. Here is an example. When one dies, or otherwise exits a universe (we should not assume that death is universal in alternative universes), one undergoes a transfer to outside of that universe. At that point, one has an immediate memory of life in the universe one has left and of all previous universes one has inhabited. The extent of the memory will depend on how much has to be remembered to fill God's purposes. One knows previous lives as her life, thus able to integrate the latest universe into her accumulated trans-universe memories. A person is now able to look back on that life and draw lessons from it for the future. God has created only people who will in fact draw conclusions from the way life was back then. Taking it all to heart, the person is now placed in another universe with a personality consequently different from that of the previous universe to the extent of having been able to learn from the past lives as remembered. One might start out in a new universe closer to God than before or it might take several universes for a person to start to become closer to God.

On my theodicy, one does not go from one universe to the next as a result of having 'failed' in the previous universe. One does not continue to go from universe to universe as a result of having been unsuccessful in extricating oneself from the chain of universes. And one does not get off the universe-chain by extinguishing of self. One goes from universe to universe in an educational process that has not yet fulfilled itself. At the end the educational process is complete. The chain of universes is not an evil, but a good that God has created for our benefit. And we need not think of there being a fantastic number of successive universes each 
person must inhabit in order to become redeemed from self-centredness. We can be assured that God would not allow more suffering than necessary. The number of universes a given person must live through might be quite small in number.

God, Ruler of the universes, gives life to the dead. God, Ruler of the universes, brings death (or its equivalent), the condition of our entering into new universes in which we will come yet closer to God. We are to praise God for death for its being the condition for the following life.

My theodicy leaves open whether religious doctrines about historical events in our universe are to be confined to our universe or are valid in other universes as well, or whether such events are instantiations of metaphysical principles enjoying different instantiations elsewhere. The application of my theodicy to Judaism need not assume that something equivalent to the Jewish people and the Torah exist in more than our universe. A Christian might want the Word to be a trans-universe reality. But she better be cautious about claiming that the Word becomes exactly 'flesh' in every universe, rather than some other material of which persons can be made. For that matter, in some universes the Word might instantiate simply as a spiritual being in fellowship with other spirits. Becoming 'one of us' could amount to something very different in universes other than ours.

In light of the above, how are we to understand the nature and purpose of our present universe in the scheme of things? How does my multiverse theodicy scale-down to a theodicy of this universe in particular?

A theodicy can be either event-based or universe-based, or a combination of both. An event-based theodicy for a universe, U, offers a justification for evil in $U$ that applies to the specific evils in $U$. For example, one might propose an event-based theodicy in which everything bad that happens in our universe is punishment for a sin committed in this universe or in previous universes. Or, one might propose that all the natural evil in Universe \#8 is due to the free-willed rebellion of angels. In a universe-based theodicy for $\mathrm{U}$, in contrast, one would explain why God is justified in creating $U$, by reference to global features of $U$, without giving specific justifications for the specific evils in U.

My theodicy for our universe is universe-based, giving a live possibility of what justifies God in having created a universe like ours. ${ }^{7}$ Our universe

${ }^{7}$ In this I follow a similar tack taken by Van Inwagen when he writes: 'Do not attempt any solution to this problem [of evil] that entails that every particular evil has a purpose, 
appears to be one in which persons and societies are subject to much chance, and are affected by impersonal forces taking no account of merit and demerit. There seems to be little ratio between being a victim and the degree to which the victim deserves such treatment. The fate of so many people seems to depend on the whims of other people, or haphazard occurrences in nature with no apparent logic to the results.

One could reply that this is all mere appearance, while the truth lies on the side of believing that every evil event in our universe is just and proper for reasons one would be prepared to venture in a theodicy. My universe-based theodicy does not go that way. Instead it acknowledges the possibility that chance does reign in our universe to a notable degree, while being consistent with higher-order divine teleology. Accordingly, I offer a reason why God would create a universe like ours, one 'governed' so much by chance.

Interestingly, several Jewish philosophers of the Middle Ages thought of our world as heavily 'governed' by chance. In The Guide of the Perplexed Maimonides wrote:

I do not by any means believe that this particular leaf has fallen because of a providence watching over it; nor that this spider has devoured this fly because God has now decreed and willed something concerning individuals. ... For all of this is in my opinion due to pure chance. ${ }^{8}$ And:

Divine providence for human beings is graded according to the degree of human perfection: Accordingly divine providence does not watch in an equal manner over all the individuals of the human species, but providence is graded as their human perfection is graded. ... As for the ignorant and disobedient, their state is despicable ... and they have been relegated to the rank of the individuals of all other species of animals. ${ }^{9}$

Nachmanides (1194-1270) took an even more restrictive view of divine providence, restricting it to the 'saintly' only:

or that, with respect to every individual misfortune...God has some special reason for allowing it.' See Peter Van Inwagen, 'The Place of Chance in a World Sustained by God', in Van Inwagen, God, Knowledge \& Mystery: Essays in Philosophical Theology (Ithaca, N.Y.: Cornell University Press, 1995), pp. $42-66$ (p. 65). See also my, 'God and Chance', in Joseph Seckbach, ed. Divine Action and Natural Selection (NY: Springer Publishing, 2008), pp. 449-462.

${ }^{8}$ Moses Maimonides, Guide for the Perplexed, translated by Shlomo Pines (Chicago: University of Chicago, 1963), p. 471.

${ }^{9}$ Maimonides, Guide, p. 475. 
God's knowledge, which is His Providence in the lowly world, pertains to the preservation of species. And also human beings are given over in [the world] to chance, until their time of judgment. However, to His saintly ones He gives attention to know him as an individual, to have His protection cling to him always. ${ }^{10}$

Similarly, Bahya ben Asher (13th century) writes that:

The providence to save one from chance events does not exist for all humans, even in Israel, except for the saintly among them, whom God saves from chance events, to which other people are given over. ${ }^{11}$

Similarly, my theodicy asserts the prevalence of chance in our universe.

So here is a description from the point of view of my universe-based justification of evil for the sector of our universe we know, earth. If persons exist elsewhere in this universe, matters might be different. On earth, persons are to a strong degree driven by self-centred needs. Persons here are the result of a long evolutionary process the key to which is survival and reproduction. Persons have central, strong drives connected to these which also lead to secondary drives for security, self-importance, status, livelihood, identity with one's family, city, country, and the like. While the degree of self-centredness lies on a continuum, the continuum is bottom heavy. Our evolutionary past has also endowed us with some reciprocal altruism interspersed with our 'selfish genes'. Yet, scattered throughout the earth (past, present, and future) are persons of high other-centred characters who float far above the sea below that extends from self-survival to self-indulgence. In addition, other persons often are able to act with a degree of genuine altruism, generally far outmatched by their self-absorption.

Self-centredness on earth is the cause of suffering in two ways. Persons cause suffering to others because of (what they take to be) their own self-interest. Thoughtlessness, indifference, jealousy, cruelty, anger, and violence are symptoms of a self-regard that acts without adequate concern for others. Wars and social upheavals are the same on a largescale. Economic and political institutions, even when designed not to, inflict great sorrow and unhappiness, not to speak of abuses of economic and political power, as further consequences of self-absorption. Other

${ }^{10}$ Moses Nachmanides, Commentary on the Torah (Jerusalem: Mosad Harav Kook, 1994/5), on Genesis 18:19. (My translation.)

${ }^{11}$ Bahya bar Asher, Midrash Rabbi Bahya on the Five Books of the Torah (Israel: np. n.d.), on Genesis 18:19. (My translation and my emphasis.) 
persons and social structures surround persons that hurt them in a variety of ways or do not sufficiently protect them from suffering, largely because of the self-centred thrust of society. Nationalism, an extension of self-centredness, makes for wars and misery. For too many people on earth, 'Hell is other people.'

Because God has created us we know that such immoral behaviour can be overcome, to the extent possible for created beings, and to an extent God deems worthwhile.

The second way self-centredness causes suffering is in the manner in which persons experience life. Ordinarily, we react to events from a perspective of self-absorption. When things do not go their way, humans will react in disappointment, sadness, or defeat. When experiencing pain, humans will respond by wanting only to escape the pain - often futilely. They will suffer from pain. The phenomenology of pain is distinct from that of suffering, the latter an overlay on the former. Yet, we standardly will take pain in as suffering. Suffering is a sign of one experiencing pain from the perspective of self-absorption.

Sickness, floods, storms, earthquakes, and all the rest, can bring chaos to human lives, and are experienced almost exclusively in suffering and defeat. Human reactions to adversity, in principle, could be very different from what they are in fact. Yet, we are not generally capable of different reactions because of the level we are at in our self-absorption in this world.

Now, I am not intending to advocate looking with indifference on human suffering, nor am I about to suggest blaming people for the way they react to occurrences in their life. Suffering is real and we must do all we can to alleviate it. I have argued elsewhere that there being a divine justification for evil is perfectly consistent with a human obligation to eliminate suffering. ${ }^{12}$ Here, I remind the reader that the whole point of a person being placed in our world is to advance in the transformation to being other-directed, rather than self-absorbed. Persons who inhabit this world of ours are the way they need to be at this station of their trans-universe journey to pure altruistic goodness.

Examples of a different way of reacting to pain are sprinkled throughout earth's history. Prime examples are religious martyrs. The Jerusalem Talmud (Berachot, 14b) tells the story of first century Rabbi Akiva, who was being tortured to death by the Roman Officer Rufus.

${ }^{12}$ See, Jerome Gellman, 'On God, Suffering, and Theodical Individualism', European Journal of Philosophy of Religion, 1 (2010), 187-191. 
The latter saw that Rabbi Akiva was reciting the Shema prayer, a prayer saying we must love God with all our soul, while he was oblivious to the pain. Rufus thought Rabbi Akiva a magician who could nullify pain, or thought that he was simply immune to pain. But what Rabbi Akiva had achieved was immunity to reacting to pain in the usual way. He had conquered his self-absorbed response to pain, to offer his life to God at that very moment. Rabbi Akiva was in pain, but he did not suffer. Whether the story is true or only a legend is not the point. The point is that the Talmud holds up this story as an ideal in response to pain, an ideal, to be sure, not of this world, but an intimation of worlds to come.

Early Christian martyrs displayed victory over self-absorbed reactions to pain. Cast to wild animals, put on the rack, burned alive, roasted, beheaded, or stoned, they chose severe torture and death rather than denounce their Christian faith. Later, some Jews were to display similar religious loyalty facing the Catholic Inquisition. Famously, Zen Buddhists have cultivated an absolute indifference in the face of death. The Zen Master Bokoju, so it is told, stood on his head to await death, wanting to turn his death into an amusing, novel event in human history.

We do not have to go so far away in history or from our everyday experience for paradigm examples of experiencing pain without suffering. When a woman gives birth to a child she might have much pain. However, normally she would not say she had suffered when in labour. The immediate self-absorption of suffering will have been replaced utterly by what is only an enduring of pain, or even perhaps a joy in the pain, for a purpose beyond the woman's present self-concern. ${ }^{13}$

In all these cases, humans overcome the category of suffering when enduring pain. So, in principle, to the extent possible for created beings, human suffering would be overcome were we to be less self-absorbed than we are. However, generally we are not capable of standing on our heads to turn things around. In this universe, except for those souls far ahead of the rest of us, spread here and there, we might be a mixture of first time stream-enterers and others not too far ahead of those.

On earth, we learn what it is like to live dominated by chance, while being equipped with a robust quantity of self-concern and selfindulgence. We come to know what it is to experience pain as suffering. We become acquainted up close with how it is to respond to events as

${ }^{13}$ I thank David Shatz for this example, which he attributes to Rabbi Joseph B. Soloveitchik. 
disappointments, and causes of paralyzing sadness. We understand what it is to be driven by an inborn need to survive and reproduce. And we know all too well the anxiety, fear, and anger when we feel that these are threatened, either realistically or potentially. Many of us discover what it is to experience an entire life in defeat.

Our lives include visibly immoral persons on their own trek to God, who image for us the horror of immorality we are able to detect in others more easily than in ourselves. From them too we learn the price of severe self-absorption. They too have what to learn from their own self-absorption. These others, alas, might be me.

Yet, we also experience intimations of a different way, which turns aside from egotism. Reciprocal altruism (although not genuine altruism, which is for the sake of others) opens a window onto genuine love of others. Also, God provides human models of true altruism so that the rest of us can witness what God desires for us. Genuine love of mothers and fathers for their children models for us both the love of God for us and the love we are destined to have for God and for all others. Many of us manage at times to rise above the mundane to perform acts of true altruism, acts that hold a mirror before us of what we will be like in a future life.

Our life on earth is one, perhaps among many, in which we are shown the consequences of self-absorption and the ideal of self-giving. It is one in a series of universes from which, looking back at it from the vantage point of what follows, a person gains an appreciation of quite to what extent his suffering is in his hands, both as perpetrator and object of evil. With new understanding as the starting point, one continues on to the next universe-station, where one might be inclined to do more good and less evil, and where natural evils will be less numerous and less severe, to the degree one has learned his lesson in previous universes. Some universes along the way will be over-brimming with goodness and closeness to God, with only small amounts of evil. Such universes will be so in part because of their inhabitants having gained from living in earlier universes. The amount of good and freedom from suffering that accumulates at an accelerated rate through the universes we occupy, together with the rich goodness of the future Messianic Age universes, justifies the journey in the best way possible.

My theodicy does not explain animal suffering. One possibility would be to maintain that animals have human souls and so their suffering assimilates to the suffering of persons. It is most strange, though, to 
imagine an animal with a human soul. However, there is a way around this strangeness, and that is to say that souls that humans possess are not human in essence, only human in accident. Think of souls as generic, neither human nor animal in themselves, that can inhabit, indifferently, human beings, animals, or whatever bizarre forms exist for them to inhabit in other universes. Then for an animal to have a human soul would mean for it to have a soul the likes of which humans also have. Run through my earlier script for personal identity and think of animals - generally - as having yet a fuller dose of self-absorption than do human beings. The result: a theodicy for animal suffering.

A more radical solution for animal suffering would be to relinquish the ontology of discrete individuals altogether, in favour of a 'broadsoul' ontology. A 'broad-soul' would be a unitary entity that can have - temporarily - a divided consciousness. While consciously separated experiences are of the one broad-soul, the latter integrates all of them only later when a unified consciousness returns to absorb them all. This would be kind of like disconnected right and left lobes of the brain with resulting parallel consciousness. What we take to be ontologically separate human souls would be phases of broad-souls, or even of a single broad-soul. Then, we not need think of animals as suffering pain qua isolated consciousnesses, but as segments of broad-soul experiences. Animal consciousness would be phases of broad-souls, and even of a single broad-soul. Everything I have written as a theodicy for discrete persons can be transferred mutatis mutandis to broad-souls without loss. Broad-souls are persons, in my sense. It might be that our attachment to an ontology of thin-souled individuals has no more to ground it than an attachment to a sense of our own separate self, due to a dominance of 'self'-absorption, an illusionary part of this universe of ours (and of others as well, most likely).

For me, a remaining question for my theodicy of evil is Hitler, and the human demons of history like him. On the one hand, as emotionally difficult as it might be to acknowledge, the horrendous evil Hitler caused could be incorporated into an ongoing story of multiple universes and of each person coming to God within societies of supreme goodness in many universes, after utter adversity and brutal suffering in this universe. You would have to believe that the process, and the totality of good in all the universes, and the end-points, being the Messianic Universes containing each person's redemptive attachment to God, are of such supreme value as to justify the multiverse God has created. This 
should be an acceptable theistic position. Still, a problem with Hitler is my difficulty in entertaining the idea that there exists a Messianic Universe in which one such as Hitler is fully redeemed. To deny this would violate my principle of universal redemption of persons, that God creates only persons who will become good like God. I admit, though, that my difficulty imagining this might stem from my particular level of egocentric existence in this life, and that in another life I might learn to love advanced versions of those who have harmed so many in such gruesome a fashion in this life. Another possibility for me would be to declare that although Hitler is human, Hitler was not a person. Recall that in my sense a 'person' is a creature who has the capacity to come close to God by becoming good, like God. If Hitler was not a person, then God would have created him for reasons other than for Hitler's ultimate redemption. Then Hitler would play a role in God's scheme like that of natural disasters.

Does a cloud of parallel universes and does a population of universehopping persons exist? Are there really Messianic Ages in universes to come? I do not know. I do propose that it would be fitting and proper for God, of perfect goodness, perfect knowledge, including middle knowledge, and perfect power, to create them. Hence, a theistic, universebased theodicy. ${ }^{14}$

${ }^{14}$ I am greatly indebted to David Shatz for his excellent suggestions on how to improve this paper. 